\title{
Evaluation of Time to Reach Primary Percutaneous Coronary Intervention in Patients with ST-Segment Elevation Myocardial Infarction Presenting to the Emergency Department
}

\author{
Acil Servise Bașvuran ST Segment Elevasyonlu Miyokart Infaktüslü Hastaların Primer \\ Perkütan Koroner Girișime Ulașma Sürelerinin Değerlendirilmesi
}

\author{
Aylin Erkek ${ }^{1}$, Huseyin Cahit Halhalli', Emrah Celik ${ }^{1}$, Sedat Avci ${ }^{2}$ \\ ${ }^{1}$ Emergency Medicine Clinic; ${ }^{2}$ Cardiology Clinic, Kocaeli Derince Training and Research Hospital, University of Health Sciences, Kocaeli, Turkey
}

\begin{abstract}
Aim: There are strong recommendations regarding the duration of the primary percutaneous coronary intervention (PCI) in STsegment elevation myocardial infarction (STEMI) patients admitted to the emergency department (ED). Determining these periods in local sources is important in comparing their compliance with current diagnosis and treatment guidelines and their effects on morbidity-mortality.
\end{abstract}

Material and Method: Patients with STEMI who applied to the ED of a tertiary education and research hospital between 01.10.2017 and 01.10.2019, accompanied by the prehospital health system or outpatient, were included in this single-center retrospective study. The time to reach $\mathrm{PCl}$ and the effects on mortality and morbidity were evaluated in patients diagnosed with STEMI in the ED or referred from an external center with the diagnosis of STEMI.

Results: 233 patients were included in the study. The mean age of the patients in the study was $61.84 \pm 11.70$, and $19.31 \%$ were female. The time to reach $\mathrm{PCl}$ was $55.55 \pm 45.08$ minutes in patients admitted directly to our hospital by ambulance, $68.27 \pm 57.15 \mathrm{~min}$ utes in outpatients, and $30.54 \pm 27.39$ minutes in patients referred from another hospital, which was significantly different $(p<0.001)$. There was no significant difference between patients with and without complications in terms of arrival time to $\mathrm{PCl}$ (medians were $37 \mathrm{vs}$ $42, p=0.054)$. There was no significant difference between the cases with a mortal course and the cases without mortality in terms of the

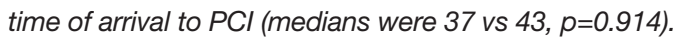

Conclusion: Although the times seem to be compatible with current guidelines, the situations that increase the average need to be revealed. In particular, it is necessary to take measures to limit the time to reach $\mathrm{PCl}$ for outpatients. In this study, although the time to reach $\mathrm{PCl}$ complies with current guidelines, it shows that other regulations are needed to reduce STEMI-related mortality.

Key words: ST-segment elevation myocardial infarction; primary percutaneous coronary intervention; emergency department

\section{ÖZET}

Amaç: Acil servise bașvuran ST segment yükselmeli miyokart infarktüsü (STEMI) hastalarında primer perkütan koroner girișim (PCl) süresi konusunda güçlü öneriler mevcuttur. Bu sürelerin yerel kaynaklardaki tayini, güncel tanı ve tedavi rehberlerine uygunluğunun ve morbidite-mortalite üzerine etkilerinin karșılaștırılması açısından önemlidir.

Materyal ve Metot: Bu tek merkezli retrospektif çalıșmaya 3. basamak eğitim araștırma hastanesi acil servisine 01.10.2017 ile 01.10.2019 tarihleri arasında hastane öncesi sağlık sistemi eșliğinde ya da ayaktan bașvuran STEMI'lü hastalar dahil edildi. Acil serviste STEMI tanısı konulan veya dıș merkezden STMI tanısı alarak sevk ile gelen hastalar hastaların PCl'a ulașma süreleri ve bu sürelerin mortalite ve morbiditeye etkileri değerlendirildi.

Bulgular: Çalıșmaya 233 hasta dahil edildi. Araștırmadaki hastaların yaș ortalaması $61,84 \pm 11,70$ ve \%19,31'i kadındı. Ambulansla direkt hastanemize bașvuran hastalarda PCl'e ulașma süresi 55,55 45,08 dakika, ayaktan direkt bașvuran hastalarda $68,27 \pm 57,15$ dakika ve bașka hastaneden sevk edilen hastalarda 30,54 $\pm 27,39$ dakika olup anlamlı olarak farklıydı ( $p<0,001)$. PCl'ya varıș süresi açısından komplikasyon gelișen ve komplikasyon gelișmeyen hastalar arasında anlamlı bir fark yoktu (sırasıyla median 37 ve 42, $p=0$,054). Mortal seyreden vakalar ile mortalite gelișmeyen vakalar arasında PCl'ye varıș zamanı açısından anlamlı bir fark bulunmadı (sırasıyla median 37 ve 43, $p=0,914$ ).

Sonuç: Her ne kadar süreler güncel klavuzlarla uyumlu görülmekte ise de, ortalamayı yükselten durumların açığa çıkarılması gerekmektedir. Özellikle ayaktan bașvuran hastaların PCl'ya ulașma sürelerini kısıtlayıcı önlemler alınması gerekmektedir. Bu çalıșmada PCl'a ulașma süreleri güncel klavuzlara uygunluk gösterse de STEMI'e bağlı mortaliteyi azaltmak açısından bașka düzenlemelere ihtiyaç olduğunu göstermektedir.

Anahtar kelimeler: ST segment yükselmeli miyokart infarktüsü; primer perkütan koroner girișim; acil servis

IIetișim/Contact: Aylin Erkek, University of Health Sciences, Kocaeli Derince Training and Research Hospital, Emergency Medicine Clinic, Kocaeli, Turkey • Tel: 05382049277 • E-mail:aylinerkek@hotmail.com • Geliș/Received:03.09.2021 • Kabul/Accepted:06.11.2021

ORCID: Aylin Erkek, 0000-0002-0432-3101 • Hüseyin Cahit Halhall, 0000-0002-0533-5593 • Emrah Celik, 0000-0001-6356-0804 • Sedat Avci, 0000-0003-3503-7033 


\section{Introduction}

Acute coronary syndrome (ACS) refers to acute chest pain resulting from impaired myocardial blood flow or other symptoms of myocardial ischemia and electrocardiographic changes that usually accompany clinical presentations due to myocardial ischemia. ACS is a series of events associated with thrombotic coronary artery disease, including non-ST-segment elevation myocardial infarction (NSTEMI), ST-segment elevation myocardial infarction (STEMI), and sudden cardiac death ${ }^{1}$.

One-third of deaths associated with myocardial infarction (MI) occur within the first few hours after the onset of symptoms ${ }^{2}$. Early application of the treatment, especially reperfusion therapy, in STEMI reduces mortality and morbidity. Reducing treatment delays increases survival, while delayed treatment results in irreversible myocardial damage and death ${ }^{3}$.

Primary percutaneous coronary intervention (PCI) is the preferred reperfusion method in patients with STEMI. The American Heart Association (AHA) 2013 STEMI guidelines recommend that primary PCI be completed within 90 minutes for STEMI patients presenting to a hospital that can perform $\mathrm{PCI}^{4} .2017$ European Society of Cardiology (ESC), in the STEMI Guidelines, the maximum time for electrocardiography (ECG) recording and diagnosis with first medical contact is 10 minutes, the time for PCI is 60 minutes if the patient applied to the center where the primary intervention was performed, and it was stated that it should not exceed a maximum of 120 minutes for patients who applied to the emergency department (ED) with the prehospital health system ${ }^{5}$. In the same guideline, the term 'time from diagnosis to PCI (wire crossing)' is used instead of the term 'door-to-balloon time' (D2B) ${ }^{5}$. In this study, we aim to determine the time to reach primary PCI in STEMI patients admitted to the $\mathrm{ED}$, evaluate the compliance of this time with current diagnosis and treatment guidelines, and compare the effects of this time on morbidity and mortality.

\section{Material and Methods}

Our retrospective study is conducted with patients diagnosed with STEMI between 01.10.2017 and 01.10.2019 in the ED of a 3rd level education and research hospital, which 400.000 patients apply annually. This study was conducted with the approval of the local ethics committee numbered 2019/123.
Our study was conducted on patients over the age of 18. Patients brought to our study with the pre-hospital health system, outpatients, and referred from external centers were included. Patients with STEMI detected in the 12-lead ECG (presence of newly developed or newly developing left bundle branch block with STsegment elevation of $0.20 \mathrm{mV}$ in males, $0.15 \mathrm{mV}$ in females or $0.1 \mathrm{mV}$ and above in other leads in at least two adjacent leads V2 and V3 and posterior myocardial infarction) made up the study population. Patients diagnosed with STEMI in the ED and STEMI patients diagnosed with STEMI in an external center and admitted to our hospital by ambulance were retrospectively scanned using hospital records. Patients admitted to the ED are welcomed by the ED senior assistant and emergency medicine specialist. The first ECG took, patient complaints, the patient's history, and physical examination findings are recorded in the patient's file by the senior assistant. If deemed necessary, consultations of the patients to the relevant departments are made by the senior assistant and emergency medicine specialist through the hospital's electronic information system. In this study, the demographic characteristics of the patients, how long they were admitted to the hospital after admission, how long it took the patients to reach PCI, which coronary artery was treated in PCI were investigated using patient files and hospital records. Admission hours to our hospital and time to reach PCI were determined for patients referred from another hospital where PCI could not be performed. The time taken for admission and referral to the previous hospital was not included in the study. The time between admission to the hospital and admission to PCI was evaluated as the "Arrival to PCI" time. Mortality and morbidity of the patients included in the study within one month after PCI was evaluated by examining hospital records. The relationship between the patients' admission time to the ED and the time to reach PCI and the development of morbidity and mortality were investigated.

\section{Statistical Analysis}

All analyses were performed on SPSS v21 (SPSS Inc., Chicago, IL, USA). For the normality check, the Kolmogorov-Smirnov test was used. Data are given as mean \pm standard deviation or median (1st quartile - third quartile) for continuous variables according to the normality of distribution and as frequency (percentage) for categorical variables. Normally distributed variables were analyzed with the analysis 
of variances (ANOVA). Non-normally distributed variables were analyzed with the Mann Whitney $U$ test or Kruskal Wallis test depending on the count of groups. Categorical variables were analyzed with the chi-square tests. Pairwise comparisons were performed with the Bonferroni correction method. Spearman correlation coefficients were calculated to evaluate relationships between continuous variables. Multiple logistic regression analyses (conditional forward method) were performed to determine risk factors of mortality. $\mathrm{p}<0.05$ values accepted as statistically significant results.

\section{Results}

Our study included 233 patients (188 males and 45 females); the mean age was $61.84 \pm 11.70$ (range 33-93). Median arrival to PCI time was 41 minutes. Arrival to PCI time was one hour or below in the 165 (70.82\%) patients while above 2 hours in the $17(7.30 \%)$ patients (Table 1). The number of patients whose first medical contact was our hospital was 163. Median arrival to PCI time for these patients was 52 (range 7 -420) minutes (Table 2). Arrival to PCI time was $55.55 \pm 45.08$ minutes in patients who first medical contact to our hospital by ambulance, $68.27 \pm 57.15$ minutes in patients who visit directly, and $30.54 \pm 27.39$ minutes in referred patients, significantly different $(\mathrm{p}<0.001)$ (Table 3).

Fifty $(21.46 \%)$ patients had known coronary artery disease, $28(12.02 \%)$ patients had a coronary stent, and $6(2.58 \%)$ patients had coronary artery by-pass graft history. Eleven $(4.72 \%)$ patients were evaluated in the green area, $96(41.20 \%)$ patients were evaluated in the yellow area, $56(24.03 \%)$ patients arrived at the hospital with an ambulance, and $70(30.04 \%)$ patients were referred from another hospital. Ninety-nine (42.49\%) patients had anterior MI, 131 (56.22\%) patients had inferior MI, and 3 (1.29\%) patients had posterior MI. The most common intervention was coronary stent (86.21\%). Half (51.93\%) of the patients applied to the hospital on weekdays between 00:00 and 15:59. The most common intervention locations were the left anterior descending artery $(40.63 \%)$ and right coronary artery $(45.98 \%)$. Seven $(3.00 \%)$ patients had restenosis, $2(0.86 \%)$ patients had ventricular tachycardia (VT) attacks, $2(0.86 \%)$ patients had atrioventricular (AV) blockage and $2(0.86 \%)$ patients had reintervention. Nineteen $(8.15 \%)$ cases were mortal; three of them were during the intervention.
Table 1. Summary of Arrival to $\mathrm{PCl}$ time

\begin{tabular}{lc}
\hline Time (minutes) & $41(24-64)$ \\
\hline$\leq 30$ & $84(36.05 \%)$ \\
$31-60$ & $81(34.76 \%)$ \\
$61-90$ & $34(14.59 \%)$ \\
$.91-120$ & $17(7.30 \%)$ \\
$>120$ & $17(7.30 \%)$ \\
\hline Data are given as median (1st quartile - 3rd quartile) or frequency (percentage)
\end{tabular}

Table 2. Summary Arrival to PCl time, referred patients excluded

\begin{tabular}{lc}
\hline Time (minutes) & $52(30-75)$ \\
\hline$\leq 30$ & $41(25.15 \%)$ \\
$31-60$ & $62(38.04 \%)$ \\
$61-90$ & $30(18.40 \%)$ \\
$91-120$ & $13(7.98 \%)$ \\
$>120$ & $17(10.43 \%)$ \\
\hline
\end{tabular}

Data are given as median (1st quartile - 3rd quartile) or frequency (percentage)

Table 3. Arrival to PCl time (minute)

\begin{tabular}{lccc}
\hline Admission & Mean & Standard deviation & $\mathrm{P}$ \\
\hline Direct visit & 68.27 & 57.15 & 0.001 \\
Direct by ambulance & 55.55 & 45.08 & \\
Referred & 30.54 & 27.39 & \\
\hline
\end{tabular}

We divided patients into three groups according to Arrival to PCI time $(\leq 30,31-60$, and $>60)$. The percentage of coronary artery disease was significantly higher in the $\leq 30$ groups than in the 31-60 group $(\mathrm{p}=0.027)$ (Table 4). Admission to green area and yellow area percentages were significantly lower in the $\leq 30$ groups than in the other groups, while referred from another hospital percentage was significantly higher in the $\leq 30$ groups than in the other groups $(\mathrm{p}<0.001)$ (Table 5). There were no significant differences between groups about age, gender, comorbidities, admission, type of MI, stenosis locations, intervention, time of admission, intervention location, length of stay in the intensive care unit, length of stay in hospital, complications, and mortality (Table 4-6).

There was no significant difference between patients with and without complications concerning Arrival to PCI time (medians were 37 vs $42, \mathrm{p}=0.054$ ). There was no significant difference between mortal and nonmortal cases concerning Arrival to PCI time (medians were 37 vs. $43, p=0.914$ ). We found no significant 
Table 4. Summary of patients demographics and history with regard to groups

\begin{tabular}{|c|c|c|c|c|c|}
\hline & \multicolumn{4}{|c|}{ Arrival to $\mathrm{PCl}$ time (minutes) } & \multirow[b]{2}{*}{$\mathrm{p}$} \\
\hline & $\leq 30(n=84)$ & $31-60(\mathrm{n}=81)$ & $>60(n=68)$ & Total $(\mathrm{n}=233)$ & \\
\hline Age & $61.01 \pm 12.67$ & $63.38 \pm 10.73$ & $61.01 \pm 11.56$ & $61.84 \pm 11.70$ & 0.340 \\
\hline \multicolumn{6}{|l|}{ Gender } \\
\hline Male & $69(82.14 \%)$ & $69(85.19 \%)$ & $50(73.53 \%)$ & $188(80.69 \%)$ & 0.183 \\
\hline Female & $15(17.86 \%)$ & $12(14.81 \%)$ & $18(26.47 \%)$ & 45 (19.31\%) & \\
\hline CAD history & $26(30.95 \%)^{a}$ & $12(14.81 \%)^{b}$ & $12(17.65 \%)^{\text {a }}$ & $50(21.46 \%)$ & 0.027 \\
\hline Coronary stent history & $13(15.48 \%)$ & $11(13.58 \%)$ & $4(5.88 \%)$ & $28(12.02 \%)$ & 0.169 \\
\hline CABG history & $1(1.19 \%)$ & $2(2.47 \%)$ & $3(4.41 \%)$ & $6(2.58 \%)$ & 0.458 \\
\hline Hypertension & 54 (64.29\%) & $56(69.14 \%)$ & $45(66.18 \%)$ & $155(66.52 \%)$ & 0.802 \\
\hline Diabetes mellitus & $16(19.05 \%)$ & $13(16.05 \%)$ & $16(23.53 \%)$ & 45 (19.31\%) & 0.513 \\
\hline Hyperlipidemia & $24(28.57 \%)$ & $26(32.10 \%)$ & $22(32.35 \%)$ & $72(30.90 \%)$ & 0.846 \\
\hline COPD & $3(3.57 \%)$ & $5(6.17 \%)$ & $7(10.29 \%)$ & $15(6.44 \%)$ & 0.242 \\
\hline
\end{tabular}

Table 5. Summary of patients procedural characteristics with regard to groups

\begin{tabular}{|c|c|c|c|c|c|}
\hline & \multicolumn{4}{|c|}{ Arrival to $\mathrm{PCl}$ time (minutes) } & \multirow[b]{2}{*}{$\mathrm{p}$} \\
\hline & $\leq 30(n=84)$ & $31-60(n=81)$ & $>60(\mathrm{n}=68)$ & Total $(n=233)$ & \\
\hline \multicolumn{6}{|l|}{ Admission } \\
\hline Direct visit, green area & $0(0.00 \%)^{a}$ & $7(8.64 \%)^{b}$ & $4(5.88 \%)^{b}$ & $11(4.72 \%)$ & $<0.001$ \\
\hline Direct visit, yellow area & $21(25.00 \%)^{a}$ & $38(46.91 \%)^{b}$ & $37(54.41 \%)^{b}$ & $96(41.20 \%)$ & \\
\hline Direct by ambulance & $20(23.81 \%)^{a}$ & $17(20.99 \%)$ a & $19(27.94 \%)^{a}$ & $56(24.03 \%)$ & \\
\hline Referred & $43(51.19 \%)^{a}$ & $19(23.46 \%)^{b}$ & $8(11.76 \%)^{b}$ & $70(30.04 \%)$ & \\
\hline \multicolumn{6}{|l|}{ Type of MI } \\
\hline Anterior & $37(44.05 \%)$ & $37(45.68 \%)$ & $25(36.76 \%)$ & $99(42.49 \%)$ & 0.471 \\
\hline Inferior & $46(54.76 \%)$ & $44(54.32 \%)$ & $41(60.29 \%)$ & $131(56.22 \%)$ & \\
\hline Posterior & $1(1.19 \%)$ & $0(0.00 \%)$ & $2(2.94 \%)$ & $3(1.29 \%)$ & \\
\hline \multicolumn{6}{|l|}{ Stenosis locations } \\
\hline Left main & $0(0.00 \%)$ & $0(0.00 \%)$ & $1(1.47 \%)$ & $1(0.43 \%)$ & 0.296 \\
\hline Left anterior descending & $44(52.38 \%)$ & $48(59.26 \%)$ & $33(48.53 \%)$ & $125(53.65 \%)$ & 0.407 \\
\hline Circumflex & $20(23.81 \%)$ & $22(27.16 \%)$ & $21(30.88 \%)$ & $63(27.04 \%)$ & 0.621 \\
\hline Right coronary artery & $47(55.95 \%)$ & $40(49.38 \%)$ & $36(52.94 \%)$ & $123(52.79 \%)$ & 0.699 \\
\hline \multicolumn{6}{|l|}{ Intervention } \\
\hline $\mathrm{PCl}$ & $6(7.23 \%)$ & $7(8.64 \%)$ & $2(2.94 \%)$ & $15(6.47 \%)$ & 0.652 \\
\hline Balloon & $5(6.02 \%)$ & $6(7.41 \%)$ & $6(8.82 \%)$ & $17(7.33 \%)$ & \\
\hline Stent & $72(86.75 \%)$ & $68(83.95 \%)$ & $60(88.24 \%)$ & $200(86.21 \%)$ & \\
\hline \multicolumn{6}{|l|}{ Time of admission } \\
\hline Weekdays 00:00-07:59 & $29(34.52 \%)$ & $17(20.99 \%)$ & $15(22.06 \%)$ & $61(26.18 \%)$ & 0.502 \\
\hline Weekdays 08:00-15:59 & $20(23.81 \%)$ & $22(27.16 \%)$ & $18(26.47 \%)$ & $60(25.75 \%)$ & \\
\hline Weekdays 16:00-23:59 & $12(14.29 \%)$ & $12(14.81 \%)$ & $12(17.65 \%)$ & $36(15.45 \%)$ & \\
\hline Weekend 00:00-07:59 & $8(9.52 \%)$ & $11(13.58 \%)$ & $12(17.65 \%)$ & $31(13.30 \%)$ & \\
\hline Weekend 08:00-15:59 & $10(11.90 \%)$ & $9(11.11 \%)$ & $4(5.88 \%)$ & $23(9.87 \%)$ & \\
\hline Weekend 16:00-23:59 & $5(5.95 \%)$ & $10(12.35 \%)$ & $7(10.29 \%)$ & $22(9.44 \%)$ & \\
\hline
\end{tabular}

Data are given as mean \pm standard deviation or median (1st quartile - 3rd quartile) for continuous variables according to normality of distribution and as frequency (percentage) for categorical variables. PCl, percutaneous coronary intervention; Ml, myocardial infarction. Same letters denote the lack of statistically significant difference between groups. 
Table 6. Summary of intervention with regard to groups

\begin{tabular}{|c|c|c|c|c|c|c|}
\hline \multirow[b]{2}{*}{ Intervention location } & \multicolumn{5}{|c|}{ Arrival to PCI time (minutes) } & \multirow[b]{2}{*}{$\mathrm{p}$} \\
\hline & $\leq 30(n=84)$ & $31-60(n=81)$ & $>60(\mathrm{n}=68)$ & & Total $(n=233)$ & \\
\hline Left main & $0(0.00 \%)$ & $4(5.26 \%)$ & $1(1.49 \%)$ & & $5(2.23 \%)$ & 0.204 \\
\hline Left anterior descending & $34(41.98 \%)$ & $31(40.79 \%)$ & $26(38.81 \%)$ & & $91(40.63 \%)$ & \\
\hline Circumflex & $6(7.41 \%)$ & $8(10.53 \%)$ & $11(16.42 \%)$ & & $25(11.16 \%)$ & \\
\hline Right coronary artery & $41(50.62 \%)$ & $33(43.42 \%)$ & $29(43.28 \%)$ & & $103(45.98 \%)$ & \\
\hline Length of stay in ICU & $2(2-3)$ & $2(1-2)$ & $2(1-3)$ & & $2(1-3)$ & 0.393 \\
\hline Length of stay in hospital & $3(2-4)$ & $3(2-4)$ & $3(2-3)$ & & $3(2-4)$ & 0.436 \\
\hline Complications & $6(7.14 \%)$ & $7(8.64 \%)$ & $0(0.00 \%)$ & & $13(5.58 \%)$ & 0.054 \\
\hline Restenosis & $4(4.76 \%)$ & $3(3.70 \%)$ & $0(0.00 \%)$ & & $7(3.00 \%)$ & \\
\hline VT attacks & $2(2.38 \%)$ & $0(0.00 \%)$ & $0(0.00 \%)$ & & $2(0.86 \%)$ & \\
\hline AV blockage & $0(0.00 \%)$ & $2(2.47 \%)$ & $0(0.00 \%)$ & & $2(0.86 \%)$ & \\
\hline Reintervention & $0(0.00 \%)$ & $2(2.47 \%)$ & $0(0.00 \%)$ & & $2(0.86 \%)$ & \\
\hline Mortality & $7(8.33 \%)$ & $6(7.41 \%)$ & $6(8.82 \%)$ & & $19(8.15 \%)$ & 0.949 \\
\hline Referred excluded mortality & $3(7.32 \%)$ & $3(4.84 \%)$ & $5(8.33 \%)$ & & $11(6.75 \%)$ & 0.733 \\
\hline \multicolumn{7}{|c|}{$\begin{array}{l}\text { Data are given as mean } \pm \text { standard deviation or median (1st quartile }-3 r d \text { quartile) for continuous variables according to normality of distribution and as frequency (percentage) for categorical variables. ICU, } \\
\text { intensive care unit; VT, ventricular tachycardia; AV, atrioventricular. Same letters denote the lack of statistically significant difference between groups. }\end{array}$} \\
\hline & $\beta$ coefficient & Standard Error & $p$ & $\operatorname{Exp}(\beta)$ & \multicolumn{2}{|c|}{$95 \%$ Cl for $\operatorname{Exp}(\beta)$} \\
\hline Age & 0.084 & 0.027 & 0.002 & 1.087 & 1.030 & 1.147 \\
\hline Female gender & 1.386 & 0.651 & 0.033 & 3.998 & 1.116 & 14.328 \\
\hline Left anterior descending stenosis & 1.584 & 0.653 & 0.015 & 4.872 & 1.355 & 17.523 \\
\hline Complication & 3.940 & 0.855 & $<0.001$ & 51.436 & 9.635 & 274.601 \\
\hline Constant & -9.936 & 2.144 & $<0.001$ & & & \\
\hline
\end{tabular}

Dependent variable: Mortality; Nagelkerke $\mathrm{R}^{2}=0.363$; Correct prediction $=92.70 \%$; $\mathrm{Cl}$, confidence interval.

correlation between Arrival to PCI time and age $(\mathrm{r}=$ 0.013, $\mathrm{p}=0.844$ ), Arrival to PCI time, and length of stay in an intensive care unit $(\mathrm{r}=-0.079, \mathrm{p}=0.229)$, Arrival to PCI time, and length of stay in hospital ( $\mathrm{r}=-$ $0.052, \mathrm{p}=0.433)$.

We performed multiple logistic regression analyses to determine significant risk factors of mortality. We found that the risk of mortality increases with age $(p=0.002)$. Female patients had a 3.998-fold higher risk of death than male patients (OR: 3.998, 95\% CI: $1.116-14.328, \mathrm{p}=0.033)$. Patients with left anterior descending artery stenosis had a 4.872-fold higher risk of death than the other patients (OR: 4.872, 95\% CI: $1.355-17.523, \mathrm{p}=0.015)$. Patients who had a complication during/after the intervention had a 51.436fold higher risk of death than the other patients (OR: 51.436, 95\% CI: 9.635-274.601, $\mathrm{p}<0.001)$. Other variables included in the model, Arrival to PCI time $(p=0.219)$, coronary artery disease history $(p=0.497)$, coronary stent history $(\mathrm{p}=0.431)$, coronary artery bypass graft history $(\mathrm{p}=0.287)$, admission unit $(\mathrm{p}=0.975)$, type of MI $(p=0.985)$ and time of admission $(p=0.948)$ were found to be non-significant (Table 7).

\section{Discussion}

Our study once again emphasizes the importance of the time to reach PCI in patients with STEMI.

STEMI account for approximately $25 \%$ to $40 \%$ of acute myocardial infarction (AMI) cases. Although inhospital mortality rates of 5-6\% and annual mortality rates of $7-18 \%$, and STEMI-related mortality have decreased in recent years, they are still an important cause of mortality ${ }^{4}$. 
Delays in treatment lead to increased mortality and deterioration of cardiac functions. D2B, the time between hospital arrival and PCI, is strongly associated with survival in STEMI patients. It is recommended that more than $75 \%$ of STEMI patients have a D2B time of fewer than 90 minutes ${ }^{6}$.

The demographic characteristics of the patients in our study are similar to those of published studies. 19.31\% of the patients included in our study were female, and $21.46 \%$ had a history of coronary artery disease. Hypertension (66.52\%) was the most common comorbidity. Similar to other studies, the left anterior (LAD) and right coronary arteries $(40.63 \%, 45.98 \%$, respectively) were found to be the coronary arteries with the most stenosis ${ }^{7,8}$. The rate of reaching PCI in $30 \mathrm{~min}$ utes or less in patients with a history of coronary artery disease was statistically significantly higher than the other patient groups $(\mathrm{p}=0.027)$.

The first place of application for $69.95 \%$ of the patients included in our study was the ED of our hospital, $45.9 \%$ were outpatients, and $24.03 \%$ of them came to our ED with the pre-hospital emergency health system (EMS). $85.4 \%$ of patients achieved PCI in less than 90 minutes. On the other hand, in $81.59 \%$ of the patients whose first referral center is our hospital, the time to reach PCI is less than 90 minutes. The time to reach PCI was found to be $68.27 \pm 57.15$ minutes for outpatients and $55.55 \pm 45.08$ minutes for patients presenting with EMS. While $66.07 \%$ of the patients who came with EMS, which was the first place of application to our hospital, reached PCI under 60 minutes, $61.68 \%$ of the outpatients reached PCI below 60 minutes. There was a significant difference between the patient groups, divided into three according to the time to reach PCI and how they applied. While $55.55 \%$ of the patients in the 31-60 group, who had time to reach PCI, applied directly to our ED, 20.99\% of this group consisted of patients who came directly to our ED by ambulance. While the rate of reaching PCI at 30 minutes and less in outpatients was significantly lower than the other groups, the rates of reaching PCI in 30 minutes and less in patients referred from another hospital were significantly higher than the other groups (25\%, 51.19\%, respectively; p: <0.001). The EMS informing the referred patients before they come to our hospital and the catheter laboratory is activated, the short time to reach PCI can be explained. However, our study did not determine how long it took the referred patients to come to our hospital from the first center they applied. In the TURKMI study, Erol MK et al. ${ }^{9}$ reported that from arrival to the first hospital to reach the second hospital was 120 minutes In the same study, similar to ours, most of the patients (49.5\%) came by themselves, $11.8 \%$ by EMS ambulance. It was found that EMS transferred $38.6 \%$ from another hospital where PCI could not be performed, and the D2B time was 36 minutes. In another study published in Turkey, the mean D2B time was 98 minutes in patients who applied directly and underwent PCI and 228 minutes in those who were referred ${ }^{10}$. In another study conducted with 43801 patients, the D2B time was 83 minutes, and $57.9 \%$ of the patients had a D2B time of fewer than 90 minutes ${ }^{7}$.

Eleven patients who applied to our ED with atypical findings (long-standing pain, weakness, epigastric pain, etc.) were diagnosed with STEMI. None of these patients could reach PCI in less than 30 minutes. In the study of Takuya Nakahashi et al., $40 \%$ of AMI patients presenting with atypical symptoms had a D2B time under 90 minutes, while $66.3 \%$ of patients presenting with typical symptoms had a D2B time under 90 minutes. Patients presenting with atypical symptoms in AMI patients had a long time to reach PCI and high 30-day mortality ${ }^{11}$.

For STEMI patients presenting to a hospital capable of performing PCI in the AHA, it is recommended that the primary PCI procedure be completed within 90 minutes. In our study, the meantime to reach PCI was calculated as 41 minutes for all patients and 52 minutes for patients whose first application was the ED of our hospital. There was no significant difference between patients with and without complications in terms of arrival time to PCI (medians were 37 vs $42, \mathrm{p}=0.054$ ). There was no significant difference between the cases with a mortal course and the cases without mortality in terms of the time of arrival to PCI (medians were 37 vs $43, \mathrm{p}=0.914$ ). There was no significant relationship between the time to reach PCI and mortality. The mortality rate was calculated as $8.15 \%$, and it was found to be higher than in other studies ${ }^{10,12}$. When patients referred from another hospital are excluded, the mortality rate drops to $6.75 \%$. This may be due to the delay in the diagnosis period of the patients who came with a referral in the center they applied to before coming to our hospital and the long referral duration. Many studies have reported that shortening 
the D2B time increases survival ${ }^{13-15}$. In the study of Cannon et al., it was shown that if the $\mathrm{D} 2 \mathrm{~B}$ duration is longer than 2 hours, there will be a $41-62 \%$ increase in in-hospital mortality ${ }^{16}$. However, there are also studies showing that shortening the D2B time does not affect mortality. In a study evaluating the effect of D2B time on mortality, including 96.738 patients with STEMI who underwent primary PCI between 2005 and 2009, D2B time decreased from 83 minutes to 67 minutes over the years. However, in-hospital mortality (5.0\% in 2005-2006 and 4.7\% in 2008-2009) was unchanged. Although national D2B improved significantly in patients undergoing primary PCI for their STEMI, in-hospital mortality remained virtually unchanged ${ }^{12}$.

In our study, it was also found that mortality increased with age $(p=0.002)$. The risk of death in female patients was 3.998 times higher than in male patients (OR: 3.998, 95\% CI: 1.116-14.328, $\mathrm{p}=0.033$ ). Similarly, in a study, in-hospital and 30-day mortality in STEMI patients was higher in women ${ }^{17,18}$. In addition, in our study, the risk of death in patients with left anterior coronary artery stenosis was found to be 4.872 times higher than in other patients, consistent with the literature (OR: 4.872, 95\% CI: 1.35517.523, $\mathrm{p}=0.015)^{4}$.

In this study, although the time to reach PCI complies with current guidelines, it shows that there is a need for shortening the time to reach PCI and additional strategies to reduce in-hospital mortality.

\section{Limitations}

Our study has several limitations that should be considered. First, the time of onset of symptoms was not evaluated in our study. We could not assess the relationship between the time from onset of symptoms to reaching PCI and mortality. In addition, the application times of the patients who came to our hospital with a referral from another hospital where PCI could not be performed and the time elapsed until they came to our hospital were not included in our study. Our study aimed to evaluate the time it takes to reach PCI and its effect on the survival of patients admitted to our hospital and guide our improvement efforts within the hospital. The time of arrival of the patients coming from an external center to our hospital is under the control of the pre-hospital health system, so it will not be affected by our in-hospital improvement efforts.

\section{References}

1. Ahcar SA, Kundu S, Norcross WA. Diagnosis of acute coronary syndromes. Am Fam Physician 2005;72:119-26.

2. Goldstein P, Lapostolle F, Steg G, Danchin N, Assez N, Montalescot G, etal. Lowering mortality in ST-elevation myocardial infarction and non-ST-elevation myocardial infarction: key prehospital and emergency room treatment strategies. Eur J Emerg Med 2009;16:244-55.

3. Akihiro Kobayashi, Naoki Misumida, Shunsuke Aoi, Eric Steinberg, Kathleen Kearney, John T. Fox, et al. STEMI notification by EMS predicts shorter door-to-balloon time and smaller infarct size. American Journal of Emergency Medicine 2016;34:1610-1613.

4. O'Gara PT, Kushner FG, Ascheim DD, Casey DE, Chung MK, de Lemos JA, et al 2013 ACCF/AHAGuideline for the Management of ST-Elevation Myocardial Infarction. Journal of the American College of Cardiology 2013;61(4): e78.

5. Ibanez B, James S, Agewall S, Antunes MJ, Bucciarelli-Ducci C, Bueno H, et al.;ESC Scientific Document Group 2017 ESC Guidelines for the management of acute myocardial infarction in patients presenting with ST-segment elevation: The Task Force for the management of acute myocardial infarction in patients presenting with ST-segment elevation of the European Society of Cardiology (ESC). Eur Heart J 2018;39:119-77.

6. Krumholz HM, Bradley EH, Nallamothu BK, Ting HT, Batchelor BW, Kline-Rogers EK, et al. A campaign to improve the timeliness ofprimary percutaneous coronary intervention: Door-to-Balloon: An Alliance for Quality. JACC Cardiovasc Interv 2008;1:97-104.

7. Rathore SS, Curtis JP, Chen J, Wangj Y, Nallamothu BK, Epstein $\mathrm{AJ}$, et al. Associationof door-to-balloon time and mortality in patients admitted to hospital with ST elevation myocardial infarction: national cohort study. BMJ 2009;338: b1807.

8. Özdemir M, Aladağ, N, Mutluer FO, Şahin M. Kliniğimize ST Yükselmeli Miyokart İnfarktüsü Nedeniyle Başvuran Hastalarda Tercih Edilen Tedavi Stratejilerinin Karşılaştırılması (Yaşam İçin Trombolitik Tedavi). Koşuyolu Heart Journal 2015;18(3):121-125.

9. Erol MK, Kayıkçığlu M, Kılıçkap M, Güler A, Öztürk Ö, Tuncay B, et al. Time delays in each step from symptom onset to treatment in acute myocardial infarction: Results from a nationwide TURKMI registry. Anatol J Cardiol 2021;25:294-303.

10. Karaarslan Ş, Alihanoğlu Yİ, Yıldız BS, Sönmez O, Soylu A, Bacaksiz A, et al. Appropriateness of the current guidelines on reperfusion treatment for patients applying to our hospital with ST-segment elevation acute myocardial infarction. Turk Kardiyol Dern Ars 2012;40:493-8.

11. Nakahashi T, Sakata K, Masuda J, Kumagai N, Higuma T, Ogimoto A, et al. Comparison of Door-to-Balloon Time and 30-Day Mortality According to Symptom Presentation in Patients With Acute Myocardial Infarction. Circ Rep 2021;3(4):194-200. 
12. Menees DS, Peterson ED, Wang Y, Curtis JP, Messenger JC, Rumsfeld JS, et al. Door-to-balloon time and mortality among patients undergoing primary PCI. N Engl J Med 2013;369:901909.

13. Park J, Choi KH, Lee JM, Kim HK, Hwang D, Rhee TM, et al. KAMIR-NIH (Korea Acute Myocardial Infarction RegistryNational Institutes of Health) Investigators. Prognostic Implications of Door-to-Balloon Time and Onset-to-Door Time on Mortality in Patients With ST -Segment-Elevation Myocardial Infarction Treated With Primary Percutaneous Coronary Intervention. J Am Heart Assoc 2019;8(9): e012188.

14. Chen FC, Lin YR, Kung CT, Cheng CI, Li CJ. The Association between Door-to-Balloon Time of Less Than 60 Minutes and Prognosis of Patients Developing ST Segment Elevation Myocardial Infarction and Undergoing Primary Percutaneous Coronary Intervention. Biomed Res Int 2017;2017:1910934.
15. Nallamothu BK, Normand SL, Wang Y, Hofer TP, Brush JE Jr, Messenger JC, et al. Relation between door-to-balloon times and mortality after primary percutaneous coronary intervention over time: a retrospective study. Lancet 2015;385:1114-1122.

16. Cannon CP, Gibson CM, Lambrew CT, Shoultz DA, Levy D, French WJ, et al. Relationship of symptom-onset-to-balloon time and door-to-balloon time with mortality in patients undergoing angioplasty for acute myocardial infarction. JAMA 2000;283(22):2941-7.

17. Murphy AC, Yudi MB, Farouque O, Dinh D, Duffy SJ, Brennan A, et al. Impact of Gender and Door-to-Balloon Times on Long-Term Mortality in Patients Presenting With ST-Elevation Myocardial Infarction. Am J Cardiol 2019;124(6):833-841.

18. Bolatkale M, Acara AC. A Novel Index for Prompt Prediction of Severity in Patients with Unstable Angina Pectoris. Emerg Med Int 2020;2020:7651610. 